A N N A L ES

UNIVERSITATIS MARIAE CURIE-SKŁODOWSKA

LUBLIN - POLONIA

VOL. LXIII, 1

SECTIO G

2016

Uniwersytet Marii Curie Skłodowskiej w Lublinie

marek.kulik@poczta.umcs.lublin.pl

MAREK KULIK

\title{
Zmiany przepisów dotyczących przedawnienia wprowadzone ustawą z dnia 20 lutego 2015 r. o zmianie ustawy - Kodeks karny oraz niektórych innych ustaw
}

Changes to the Rules on Limitation Made by the Act of $20^{\text {th }}$ February 2015 Amending the Act - the Penal Code and Some Other Laws

Ustawa z dnia 20 marca 2015 r. o zmianie ustawy - Kodeks karny oraz niektórych innych ustaw ${ }^{1}$ przyniosła najobszerniejszą $\mathrm{z}$ dotychczas przeprowadzonych zmian kodeksu karnego. Dotyczyła zagadnień podstawowych, w odniesieniu do niektórych przyniosła zmiany kluczowe. W wypadku przedawnienia karalności i przedawnienia wykonania kary zmiany nie spowodowały przekonstruowania instytucji, dotyczyły jednak kwestii na tyle istotnych, że warto poświęcić im kilka uwag szczegółowych.

Jak stwierdzono, ustawa nowelizacyjna nie spowodowała zmian w zakresie samej istoty przedawnienia karalności i przedawnienia wykonania kary, choć być może mogła i powinna była to uczynić. De lege lata zachowały aktualność spory dotyczące samej istoty przedawnienia karalności i przedawnienia wykonania kary, które nabierają szczególnego znaczenia zwłaszcza w kontekście zmian legislacyjnych dotyczących jednej i drugiej instytucji. Nie wchodząc w ich istotę, można uważać, że przedawnienie jest instytucją karnoprocesową lub karnomaterialną, ewentualnie mieszaną, bądź też - jak autor niniejszych słów - zająć stanowisko nietypowe, uznać przedawnienie karalności za instytucję prawa materialnego, a przedawnienie wykonania kary - za instytucję procesową2. Rozstrzygnięcie sporu o jurydyczny

1 Dz.U. z 2015 r., poz. 396.

2 Nie ma tu miejsca na szczegółowy przegląd stanowisk w tej mierze, tym bardziej że zostało to ostatnio uczynione w literaturze dwukrotnie: K. Banasik, Przedawnienie w prawie karnym w systemie kontynentalnym i anglosaskim, Warszawa 2013, s. 262; M. Kulik, Przedaw- 
charakter przedawnienia ma znaczenie właśnie w wypadku zmiany ustawy karnej. Uznanie obu instytucji za procesowe wyłącza je spod działania art. 4 k.k. i pozwala dowolnie kształtować jego termin w odniesieniu do już popełnionych przestępstw, jeżeli jeszcze nie upłynął. Przyjęcie, że są to instytucje prawa materialnego, powoduje konieczność uwzględnienia art. 4 k.k. To z kolei stawia problem, czy dopuszczalne są ustawowe klauzule wyłączające zastosowanie art. 4 k.k. do terminów przedawnienia karalności, które tą ustawą zostają wydłużone. Uznanie instytucji za mieszaną w zasadzie niczego nie wnosi, ponieważ w praktyce oznacza to konieczność ustalenia, czy owa mieszana instytucja jest „bardziej” procesowa czy „bardziej” materialna. Przyjęcie koncepcji prezentowanej przez autora niniejszych słów oznaczałoby, że zmiana normatywna w zakresie przedawnienia karalności jest oceniana tak, jak ma to miejsce na gruncie prawa karnego materialnego, a zatem w grę wchodzi zastosowanie art. 4 k.k., natomiast w przypadku przedawnienia wykonania kary wydłużenie terminu wykonania już orzeczonej kary jest możliwe, jeżeli termin ten jeszcze nie upłynął. Ustawa z dnia 20 marca 2015 r. nie wprowadziła w tym zakresie żadnych zmian, dlatego wolno nadal twierdzić, że przedawnienie karalności jest instytucją materialną, a przedawnienie wykonania kary - procesową ${ }^{3}$, choć za-

nienie karalności i przedawnienie wykonania kary w polskim prawie karnym, Warszawa 2014, s. 77-93.

3 Pogląd ten, wypowiedziany i szczegółowo uzasadniony przez autora niniejszych słów na początku 2014 r. (M. Kulik, Przedawnienie..., s. 100-101), nie spotkał się jak dotąd (sierpień 2015 r.) ani $\mathrm{z}$ akceptacją, ani z negacją, poza jednym przypadkiem. Dyskusję z nim podjął $\mathrm{S}$. Tarapata, stawiając mu cztery zarzuty. Po pierwsze, przedawnienie karalności ,jest elementem polityki karnej”, co oznacza, że jego celem jest to, by po upływie pewnego czasu nie ograniczać jednostki w przysługujących jej prawach lub wolnościach, gdyż dezaktualizują się cele kary. Po drugie, gdyby przedawnienie wykonania kary było instytucją procesową, do jego obliczania należałoby stosować przepisy k.p.k., co jest „w przeważającej części zasadnie odrzucane zarówno w orzecznictwie, jak w piśmiennictwie". Po trzecie, stosowanie instytucji po uprawomocnieniu się kary nie nadaje jej procesowej proweniencji, czego przykładem jest zatarcie skazania. Po czwarte, w razie stwierdzenia, że jest to instytucja procesowa, „kłopotliwe byłoby stosowanie art. $4 \S 1$ k.k. w wypadkach, kiedy po tym, jak danej osobie przedawniłoby się już wykonanie orzeczonej kary, wydłużone zostałyby terminy takiego przedawnienia”. Zob. S. Tarapata, [w:] Nowelizacja prawa karnego 2015. Komentarz, red. W. Wróbel, Kraków 2015, s. 778-779. Nie miejsce tu na dłuższy wywód, jednak do postawionych wyżej zarzutów można się odnieść krótko. Po pierwsze, przedawnienie nie jest „elementem”, tylko efektem, ewentualnie przejawem polityki karnej. Jako takie jest instytucją prawa karnego materialnego lub procesowego, co jest sporne. Polityka karna jest realizowana przez wprowadzanie określonych uregulowań materialnych i procesowych. Wszystkie przepisy prawa karnego materialnego lub procesowego (w szerokim rozumieniu, a zatem także wykonawczego) służą realizacji polityki karnej. To, że dana instytucja służy realizacji polityki karnej, nie sprawia, że musi być ona koniecznie uważana za materialną. S. Tarapata zdaje się kłaść nacisk na to, że cele przedawnienia wykonania kary (jego ratio legis) są materialne. To prawda. Czy jednak materialnoprawne ratio legis decyduje o materialnym charakterze przepisu? Twierdzę, że nie. Wszak ostatecznym celem procesu jest wymierzenie sprawiedliwości materialnej, a zatem realizacja przepisu prawa karnego materialnego (por. S. Waltoś, Proces karny. Zarys systemu, Warszawa 2009, s. 24). Dlatego sądzę, że wywód odnoszący się do przedawnienia jako ,elementu polityki karnej” nie jest argumentem na rzecz jego charakteru. Cele polityki karnej równie dobrze można realizować, tworząc przepisy materialne, jak procesowe. Drugi 
pewne bardziej popularny będzie nadal tradycyjny pogląd o tym, że przedawnienie jest jednolitą instytucją, której charakter jest materialny lub mieszany.

W zakresie przedawnienia karalności najistotniejsza wydaje się być zmiana wprowadzona w treści art. $101 \S 4$ k.k. Dotychczas przepis ten stanowił, że w przy-

zarzut uważam za obciążony błędem logicznym. Przecież doktryna i orzecznictwo nie dlatego uważają przedawnienie wykonania kary za materialne, bo stosują terminy materialnoprawne, ale odwrotnie - dlatego stosują terminy materialnoprawne, ponieważ większość uważa przedawnienie za instytucję materialną. Z tego samego powodu autor niniejszych słów, uważając przedawnienie wykonania kary za instytucję procesową, twierdzi, że należy do obliczania jego terminów stosować przepisy procesowe (M. Kulik, Przedawnienie ..., s. 223). Przypomnieć tylko należy, że przedawnienie często jest uważane za jedną instytucję. Uważa się ją za materialną, bo taki - bez wątpliwości - jest charakter przedawnienia karalności. Jeżeli uznać, że są to dwie różne instytucje, można już mieć wątpliwości. To jednak, jakie terminy są stosowane, to kwestia wtórna, a nie pierwotna, i nie może być argumentem dla ustalenia, jaki jest prawny charakter instytucji. Po trzecie, nigdy nie twierdziłem, że stosowanie instytucji po uprawomocnieniu się orzeczenia czyni ją procesową, nawet jeżeli z zacytowania krótkiego fragmentu dhuższego wywodu może wynikać co innego. Stwierdziłem natomiast - i powtarzam obecnie - że o ocenie danej instytucji jako materialnej lub procesowej decyduje to, jaki jest jej zasadniczy skutek prawny (ibidem, s. 95). W przypadku przedawnienia karalności jest nim ustanie karalności czynu, więc jest to instytucja materialnoprawna. W przypadku przedawnienia wykonania kary skutkiem jest niedopuszczalność postępowania wykonawczego. Oczywiście istnieje dalszy skutek na gruncie prawa materialnego - uruchomienie terminu zatarcia skazania. Jest on jednak wtórny. Każda instytucja prawnokarna - czy to materialna, czy procesowa - może wywoływać (i zwykle wywołuje) skutki zarówno materialne, jak i procesowe. Tak jest także w wypadku przedawnienia wykonania kary. Dla ustalenia jej charakteru jest istotne to, jaki jest skutek pierwotny danej instytucji. Ten w wypadku przedawnienia wykonania kary leży w procesie - przedawnienie wykonania kary przede wszystkim stanowi o niedopuszczalności postępowania wykonawczego. Jego skutek materialny to głównie niemożność wykonania kary. Jest to skutek wtórny wobec pierwotnego skutku procesowego - niedopuszczalności postępowania wykonawczego (ibidem, s. 643). Ponadto upływ terminu przedawnienia wykonania kary uruchamia termin zatarcia skazania. Trudno chyba byłoby uznać, że celem przedawnienia wykonania kary jest przede wszystkim uruchomienie terminu zatarcia skazania. Celem jest uniemożliwienie wykonania kary, a ten jest osiągany metodą procesową przez niedopuszczalność postępowania wykonawczego. Dlatego twierdzę, że przedawnienie wykonania kary jest instytucją procesową i nie czuję się przekonany do tego, że jest inaczej, argumentem o istnieniu wtórnych skutków materialnych. Wszak np. recydywa specjalna (art. 64), instytucja materialna, jest uzależniona od uprzedniego skazania, a więc zaszłości procesowej (chyba że uznamy, iż wyrok jest konstrukcją materialnoprawną). To, czy dana instytucja jest stosowana przed czy po uprawomocnieniu się orzeczenia, nie ma znaczenia. Czwarty zarzut polega na pomyłce. W wypadku wskazanym przez S. Tarapatę nie będzie żadnych kłopotów ze stosowaniem art. 4 k.k., gdyż nie ma on w nim zastosowania. Jeżeli przedawnienie wykonania kary jest instytucją procesową, art. 4 k.k. nie ma do niego zastosowania. W razie upływu terminu przedawnienia wykonania kary, a następnie jego wydłużenia, należy uznać, że termin upłynął i kary wykonać nie można (o wyjątkach zob. ibidem, s. 199-208). Warto dodać, że jest to kwestia rozumienia art. 4 k.k. Jeżeli przyjąć, że ma on zastosowanie do wszystkich przepisów materialnych, ale nie ma zastosowania do przepisów procesowych, nawet zawartych w k.k., jest tak, jak napisano wyżej. Inaczej - tak jak uważa S. Tarapata - będzie w wypadku, kiedy uznać, że art. 4 k.k. ma zastosowanie do wszystkich przepisów materialnych, a także do wszystkich przepisów zawartych w k.k., niezależnie od ich proweniencji. Nie miejsce tu na rozwijanie tego zagadnienia, stwierdzę zatem tylko, że za słuszny uważam pierwszy pogląd. Ostatecznie w zakresie prawnego charakteru przedawnienia wykonania kary pozostaję przy dotychczasowym zdaniu. 
padku, kiedy pokrzywdzony jest małoletni, przedawnienie karalności przestępstw określonych w art. 189a $\S 1$ k.k. oraz w rozdziale XXV (Przestępstwa przeciwko wolności seksualnej i obyczajności) nie może nastąpić przed ukończeniem przez pokrzywdzonego 30. roku życia ${ }^{4}$. Będzie natomiast stanowił, że w przypadku 1) występków przeciwko życiu i zdrowiu, popełnionych na szkodę małoletniego, zagrożonych karą, której górna granica przekracza 5 lat pozbawienia wolności ${ }^{5}$, 2) przestępstw określonych w rozdziale XXV, popełnionych na szkodę małoletniego albo gdy treści pornograficzne obejmują udział małoletniego - przedawnienie karalności nie może nastąpić przed ukończeniem przez niego 30. roku życia. Uzasadnieniem wprowadzenia tej regulacji jest konieczność udoskonalenia przepisu pod względem techniki legislacyjnej, a także potrzeba uzgodnienia polskich regulacji z przepisami stanowionymi przez Unię Europejską ${ }^{6}$. Chodzi - po pierwsze - o dyrektywę Parlamentu Europejskiego i Rady 2011/93/UE z dnia 13 grudnia $2011 \mathrm{r}$. w sprawie zwalczania niegodziwego traktowania w celach seksualnych i wykorzystywania seksualnego dzieci oraz pornografii dziecięcej ${ }^{7}$, a po drugie o konwencję Rady Europy z dnia 25 października 2007 r. o ochronie dzieci przed seksualnym wykorzystaniem i niegodziwym traktowaniem w celach seksualnych (Konwencja z Lanzarote) $)^{8}$.

Art. 15 ust. 2 dyrektywy 2011/93/UE zobowiązuje państwa członkowskie do podjęcia środków niezbędnych do umożliwienia ścigania wszelkich przestępstw, o których mowa w art. 3, art. 4 ust. 2, 3, 5, 6 i 7 oraz wszelkich poważnych przestępstw, o których mowa w art. 5 ust. 6, w związku z którymi wykorzystano

4 Brzmienie to przepis otrzymał ustawą z dnia 4 kwietnia 2014 r. o zmianie ustawy - Kodeks karny oraz niektórych innych ustaw (Dz.U. z 2014 r., poz. 538). Do tego czasu przepis ten w brzmieniu zmienionym przez ustawę z dnia 24 października 2008 r. (Dz.U., nr 214, poz. 1344 ze zm.) stanowił, że karalność przestępstw określonych w art. 199 § 2 i 3, art. 200, art. $202 \S 2$ i 4 oraz art. 204 $\S 2$, a także przestępstw określonych w art. 197, art. 201, art. $202 \S 3$ i art. $204 \S 4$ k.k. w przypadku, kiedy pokrzywdzonym jest małoletni, nie może nastąpić przed upływem 5 lat od ukończenia przez pokrzywdzonego 18 lat.

5 W doktrynie słusznie zwraca się uwagę, że wprowadzając takie określenie, nie dochowano zasady konsekwencji językowej w legislacji. Wyrażenie „zagrożony karą pozbawienia wolności, której górna granica przekracza 5 lat" jest językową nowością. Do tej pory nie stosowano tego typu określenia w treści k.k., używano - zresztą niekonsekwentnie - dwóch innych. Mowa była o karze przekraczającej określoną wysokość (np. art. 66 § 2 k.k.) lub karze powyżej określonej wysokości (np. art. $60 \S 8$ k.k.). Zob. J. Majewski, Kodeks karny. Komentarz do zmian 2015, Warszawa 2015, s. 394. Choćby z tego względu trudno uznać, że cel wprowadzenia przepisu, jakim było m.in. udoskonalenie legislacyjne przepisów (por. przypis następny), został osiągnięty.

6 Uzasadnienie rządowego projektu ustawy z dnia 15 kwietnia 2014 r., s. 30; S. Tarapata, [w:] Nowelizacja ..., s. 789; M. Hermanowicz, Przedawnienie w świetle projektów zmian kodeksu karnego, „Ius Novum” 2015, nr 1, s. 57.

7 Dz.Urz. U.E.L. 2011, nr 335.1.

8 Zgoda na ratyfikację została wyrażona ustawą z dnia 26 listopada 2014 r. (Dz.U. z 2014 r., poz. 1623). 
pornografię dziecięcą, o której mowa w art. 2 lit. c podpunkt (i) oraz (ii), przez wystarczający i proporcjonalny do wagi danego przestępstwa okres od momentu osiągnięcia przez pokrzywdzonego pełnoletniości. Warto już w tym miejscu zwrócić uwagę na sposób określenia czasu, przez jaki ma istnieć możliwość ścigania. Określenie to jest płynne, czas ma być „wystarczający” - zapewne do skutecznego ścigania - i ,proporcjonalny do wagi danego przestępstwa”.

$\mathrm{W}$ grę wchodzi cały szereg przestępstw. Są to:

- doprowadzenie, w celach seksualnych, dziecka, które nie osiągnęło wieku przyzwolenia, do bycia świadkiem czynności seksualnych, nawet jeżeli nie musi samo w nich uczestniczyć (art. 3 ust. 2),

- doprowadzenie, w celach seksualnych, dziecka, które nie osiągnęło wieku przyzwolenia, do bycia świadkiem niegodziwego traktowania w celach seksualnych, nawet jeżeli nie musi samo w nich uczestniczyć (art. 3 ust. 3),

- podejmowanie czynności seksualnych z udziałem dziecka, które nie osiągnęło wieku przyzwolenia (art. 3 ust. 4),

- podejmowanie czynności seksualnych z udziałem dziecka, w przypadku gdy dochodzi do nadużycia uznanego stosunku zaufania, władzy lub wpływu na dziecko (art. 3 ust. 5 i),

- podejmowanie czynności seksualnych z udziałem dziecka, w przypadku gdy dochodzi do wykorzystania szczególnej bezbronności dziecka, w szczególności wynikającej z jego niepełnosprawności umysłowej lub fizycznej lub stosunku zależności (art. 3 ust. 5 ii),

- podejmowanie czynności seksualnych z udziałem dziecka, w przypadku gdy dochodzi do użycia przymusu, przemocy lub groźby (art. 3 ust. 5 iii),

- użycie przymusu, przemocy lub groźby prowadzące do czynności seksualnych dziecka z osobą trzecią (art. 3 ust. 6),

- doprowadzenie lub nakłanianie dziecka do udziału w przedstawieniach pornograficznych lub czerpanie z tego korzyści bądź inne wykorzystywanie dziecka do takich celów (art. 4 ust. 2),

- użycie przymusu lub przemocy prowadzące do udziału dziecka w przedstawieniach pornograficznych lub użycie do takich celów gróźb w stosunku do dziecka (art. 4 ust. 3),

- świadoma obecność na przedstawieniach pornograficznych z udziałem dziecka (art. 4 ust. 4),

- doprowadzenie lub nakłanianie dziecka do udziału w prostytucji dziecięcej lub czerpanie z tego korzyści bądź inne wykorzystywanie dziecka do takich celów (art. 4 ust. 5),

- użycie przymusu lub przemocy prowadzące do udziału dziecka w prostytucji dziecięcej lub użycie do takich celów gróźb w stosunku do dziecka (art. 4 ust. 6), 
- podejmowanie czynności seksualnych z udziałem dziecka, związane z korzystaniem z prostytucji dziecięcej (art. 4 ust. 7),

- produkcja pornografii dziecięcej (art. 5 ust. 6) ${ }^{9}$.

Art. 33 Konwencji z Lanzarote nakłada na państwa-strony obowiązek podjęcia koniecznych środków, ustawodawczych lub innych, w celu zapewnienia, aby termin przedawnienia dla wszczęcia postępowania $\mathrm{w}$ związku z przestępstwami określonymi zgodnie z art. 18, 19 ust. 1 lit. a i b oraz art. 21 ust. 1 lit. a i b biegł w czasie wystarczającym dla skutecznego wszczęcia postępowania po uzyskaniu przez pokrzywdzonego pełnoletniości oraz w czasie współmiernym do ciężaru przestępstwa. W tym wypadku mamy także do czynienia $\mathrm{z}$ elastycznym określeniem czasu, przez który ma istnieć realna możliwość ścigania.

Przestępstwa, o których mowa, to:

- uczestnictwo w czynnościach seksualnych z udziałem dziecka, które zgodnie z prawem krajowym nie osiągnęło wieku umożliwiającego mu wyrażenie zgody na podejmowanie czynności seksualnych (art. 18 ust. 1 lit. a),

- uczestnictwo w czynnościach seksualnych z udziałem dziecka w przypadku: zastosowania przymusu, siły, groźby lub nadużycia zaufania, władzy lub wpływu na dziecko, w tym w ramach rodziny, lub nadużycia szczególnej sytuacji ofiary, zwłaszcza jej ułomności fizycznej lub psychicznej, lub zależności (art. 18 ust. 1 lit. b),

- umyślna rekrutacja dziecka do prostytucji lub powodowanie udziału dziecka w prostytucji (art. 19 ust. 1 lit. a),

- umyślne zmuszanie dziecka do prostytucji lub osiąganie z tego korzyści lub wykorzystywanie dziecka do tych celów w inny sposób (art. 19 ust. 1 lit. b) ${ }^{10}$,

- umyślna rekrutacja dziecka do udziału w prezentacjach pornograficznych lub powodowania udziału dziecka w takich prezentacjach (art. 21 ust. 1 lit. a),

- umyślne zmuszanie dziecka do udziału w prezentacjach pornograficznych lub czerpania z tego korzyści lub innego rodzaju wykorzystywanie dziecka do tych celów (art. 21 ust. 1 lit. b) ${ }^{11}$.

Już w tym miejscu warto zauważyć, że wprowadzona zmiana na pewno nie zwiększa ochrony małoletniego przed wykorzystaniem seksualnym. Zarówno przed jej wprowadzeniem, jak i potem termin przedawnienia karalności będzie

9 W tym ostatnim wypadku w grę wchodzą tylko poważne przestępstwa, niezależnie od tego, co miałoby to oznaczać.

${ }^{10}$ Co ciekawe, regulacje odnoszące się do przedawnienia nie dotyczą umyślnego korzystania z prostytucji dziecięcej (art. 19 ust. 1 lit. c). Przepis art. 33 konwencji mówi bowiem o art. 19 ust. 1 lit. a i b, nie mówi o lit. c. Odmiennie (omyłkowo) S. Tarapata, [w:] Nowelizacja ..., s. 791.

${ }^{11}$ Regulacje odnoszące się do przedawnienia nie dotyczą świadomego uczęszczania na prezentacje pornograficzne z udziałem dzieci (art. 21 ust. 1 lit. c). Przepis art. 33 konwencji mówi bowiem o art. 21 ust. 1 lit. a i b, nie mówi o lit. c. Odmiennie (omyłkowo) S. Tarapata, [w:] Nowelizacja..., s. 791 . 
wydłużony w wypadku przestępstw seksualnych. Różnica tkwi w tym, że w poprzednim stanie prawnym wydłużenie to dotyczyło handlu ludźmi, natomiast obecnie - poważnych występków przeciwko życiu. Należy podkreślić, że akty prawa UE, o których mowa w uzasadnieniu projektu, nie dotyczą przestępstw przeciwko życiu i zdrowiu. Wprowadzona zmiana nie jest zatem realizacją tych aktów, a wypływa zapewne z jakichś innych powodów, przy czym trudno w gruncie rzeczy zgadnąć, z jakich. Zmiana ta nie poszerzyła zakresu ochrony udzielanej małoletnim przed wykorzystaniem seksualnym. Nie znaczy to jednak, że była dla niej obojętna. Przed jej wejściem w życie wydłużenie terminu przedawnienia karalności dotyczyło przestępstwa handlu ludźmi (art. 189a § 1 k.k.), którego usunięcie zapewne nie było podyktowane żadnymi racjonalnymi przesłankami ${ }^{12}$, ale które ma znaczenie z punktu widzenia ochrony małoletniego przed wykorzystaniem seksualnym. Przecież zgodnie z art. $115 \S 22$ k.k. handlem ludźmi jest werbowanie, transport, dostarczanie, przekazywanie, przechowywanie lub przyjmowanie osoby z zastosowaniem: 1) przemocy lub groźby bezprawnej, 2) uprowadzenia, 3) podstępu, 4) wprowadzenia w błąd albo wyzyskania błędu lub niezdolności do należytego pojmowania przedsiębranego działania, 5) nadużycia stosunku zależności, wykorzystania krytycznego położenia lub stanu bezradności, 6) udzielenia albo przyjęcia korzyści majątkowej lub osobistej albo jej obietnicy osobie sprawującej opiekę lub nadzór nad inną osobą - w celu jej wykorzystania, nawet za jej zgodą, w szczególności w prostytucji, pornografii lub innych formach seksualnego wykorzystania, w pracy lub usługach o charakterze przymusowym, żebractwie, niewolnictwie lub innych formach wykorzystania poniżających godność człowieka albo w celu pozyskania komórek, tkanek lub narządów wbrew przepisom ustawy. Jeżeli zachowanie sprawcy dotyczy małoletniego, stanowi ono handel ludźmi nawet gdy nie zostały użyte metody lub środki wymienione w pkt. 1-6. Nie powinno budzić wątpliwości, że - niezależnie od swej konstrukcyjnej ułomności - typ handlu ludźmi jest ważnym elementem zwalczania przestępczości seksualnej przeciwko dzieciom i istotne jest jego włączenie do katalogu przestępstw wskazanych w art. $101 \S 4$ k.k.

Zapewne możliwe byłoby rozważenie poszerzenia katalogu przestępstw wskazanych w tym przepisie, być może nawet o niektóre przypadki przestępstw przeciwko życiu i zdrowiu. Nie wydaje się to być jednak odpowiednią metodą regulacji. Aby ją odnaleźć, należy się zastanowić, jakie są właściwie powody, dla których następuje wydłużenie przedawnienia w odniesieniu do przestępstw seksualnych. Wydaje się, że w grę wchodzą przypadki, kiedy sam pokrzywdzony nie może działać, a ten, kto miałby działać za niego, a zatem rodzice lub opiekun, nie

${ }^{12}$ Co słusznie konstatuje S. Tarapata (ibidem, s. 791-792), celnie zauważając, że nie da się odszukać racjonalnych przesłanek tej zmiany, gdyż prawdopodobnie ich nie ma. Por. M. Hermanowicz, op. cit., s. 57-58. 
czyni tego, niezależnie od powodów, z jakich to robi. Te ostatnie mogą być różne - przedstawiciel ustawowy może nie wiedzieć o sprawie, nie wierzyć pokrzywdzonemu. Niestety, stosunkowo często będzie sprawcą lub pomocnikiem w takim czynie ${ }^{13}$. Dlatego być może właściwą metodą nie jest mnożenie typów, przy których miałoby nastąpić wydłużenie terminu przedawnienia, lecz raczej wprowadzenie przestępstw popełnianych przez określone kategorie osób. Być może uzasadnione byłoby rozszerzenie go na wszystkie przypadki popełnienia czynu zabronionego przez rodziców lub opiekunów w stosunku do dzieci pozostających pod ich władzą. Przestępstwa seksualne i handel ludźmi winny pozostać w przepisie art. $101 \S 4$ k.k. w postaci niezmienionej. Obok nich należałoby jednak uwzględnić znęcanie się, przestępstwa spowodowania uszczerbku na zdrowiu, niealimentację, uporczywe nękanie. Należy rozważyć, czy nie byłoby słuszne, by uregulowanie art. $101 \S 4$ k.k. dotyczyło wszystkich przestępstw zagrożonych określoną karą (np. przekraczającą 3 lata pozbawienia wolności), popełnionych przez rodziców lub opiekunów ${ }^{14}$, a niezależnie od tego wszystkich (niezależnie, przez kogo popełnionych) przestępstw seksualnych i handlu ludźmi. Być może uregulowanie to należałoby odnieść także do przypadków, kiedy czyn zabroniony zostaje popełniony przez osobę, pod której faktyczną pieczą pozostaje pokrzywdzony ${ }^{15}$. Kształt przepisu po nowelizacji jest jednak regresem - wprowadzenie en bloc wszystkich poważnych występków przeciwko zdrowiu niczemu nie służy.

W samej długości okresu, w którym nie może nastąpić przedawnienie karalności, nie dokonano zmian. Nadal termin przedawnienia karalności nie może upłynąć przed ukończeniem przez pokrzywdzonego 30. roku życia ${ }^{16}$. Okres ten

${ }^{13}$ Badania M. Mozgawy i M. Budyn-Kulik (objęły cztery apelacje i rok 2002) wykazały, że wśród 157 skazanych sprawców czynu zabronionego przez art. 200 k.k. było 39 ojców, 14 ojczymów, 9 konkubentów matki, a więc w sporym odsetku przypadków był to albo przedstawiciel ustawowy dziecka, albo osoba $\mathrm{z}$ tym przedstawicielem związana i mająca na niego wpływ. Zob. M. Mozgawa, M. Budyn-Kulik, Prawnokarne aspekty pedofilii. Analiza dogmatyczna $i$ wyniki badań empirycznych, „Czasopismo Prawa Karnego i Nauk Penalnych” 2006, z. 2, s. 68.

${ }^{14}$ Tak proponuje O. Sitarz. Autorka podaje przykład spowodowania wypadku drogowego z pokrzywdzeniem wyłącznie osoby najbliższej dla sprawcy, zwracając uwagę, że jest to przestępstwo wnioskowe, co dodatkowo komplikuje zagadnienie. Zob. O. Sitarz, Problem przedawnienia $w$ prawie polskim i orzecznictwie ETPCz na tle przestępstw popetnionych na szkodę małoletnich, [w:] Czas i jego znaczenie w prawie karnym, red. J. Warylewski, Gdańsk 2010, s. 286-287.

${ }_{15}$ M. Kulik, Przedawnienie..., s. 500; idem, Wydtużenie terminów przedawnienia karalności przestepstw przeciwko wolności seksualnej i obyczajności popetnionych z pokrzywdzeniem małoletnich, ,Zeszyty Naukowe Wyższej Szkoły Humanistyczno-Ekonomicznej w Zamościu” 2012, nr 6, s. 127 i n.

${ }^{16}$ Słusznie pisze S. Tarapata, że termin ten nie zostanie wydłużony w wypadku, kiedy pokrzywdzony umrze przed ukończeniem 30. roku życia. Zob. S. Tarapata, [w:] Nowelizacja ..., s. 802. Ciekawa sytuacja powstaje, jeżeli pokrzywdzony umrze przed ukończeniem 30. roku życia, ale po upływie okresu, w którym przedawnienie upłynęłoby, gdyby nie zostało wydłużone. Wydaje się, że można bronić poglądu, że w takim wypadku termin przedawnienia karalności zostaje wydłużony do czasu śmierci pokrzywdzonego. Nie jest to jednak kwestia oczywista. 
został wydłużony ustawą z dnia 4 kwietnia 2014 r. o zmianie ustawy - Kodeks karny oraz niektórych innych ustaw ${ }^{17}$. Poprzednio określono go na 5 lat od ukończenia przez pokrzywdzonego 18. roku życia. Poprzednie brzmienie przepisu nasuwało kilka poważnych zastrzeżeń. Sama konstrukcja, że termin przedawnienia nie może upłynąć przed określonym momentem, jawi się jako mało naturalna, schematyczna, nie wpisuje się w siatkę pojęciową polskiego prawa karnego ${ }^{18}$. Różnicuje ona niepotrzebnie okres przedawnienia karalności w zależności od wieku pokrzywdzonego ${ }^{19}$, co zresztą w niektórych wypadkach w ogóle nie zmienia długości terminu. Nadal rodzi to wątpliwości, czy termin tak określony może być jeszcze dodatkowo przerwany ${ }^{20}$.

Te ostatnie istnieją i obecnie. Na gruncie obecnego stanu prawnego wciąż nie jest jasne, czy termin wydłużony do ukończenia przez pokrzywdzonego 30. roku życia może być przerwany i tym samym wydłużony, czy nie. Zgodnie z art. 102 k.k. bieg terminu przedawnienia zostaje przerwany w razie wszczęcia postępowania karnego przeciwko osobie w okresie przewidzianym w art. 101 k.k. Jeżeli uznać, że przepis ten dotyczy także terminu wydłużonego do ukończenia przez pokrzywdzonego 30. roku życia, to w razie wszczęcia postępowania przeciwko osobie przed ukończeniem przez pokrzywdzonego 30. roku życia termin mógłby zostać wydłużony dodatkowo w wyniku przerwania ${ }^{21}$. Można jednak uważać, że art. $101 \S 4$ k.k. nie tworzy odrębnego terminu przedawnienia karalności, a tylko stwierdza, że termin określony w art. $101 \S 1$ k.k. nie może upłynąć przed ukończeniem przez pokrzywdzonego 30. roku życia. W takim razie termin ten nie mógłby być przerwany ${ }^{22}$. Za trafne uważam pierwsze rozwiązanie. Wydaje się, że można mówić o statuowaniu przez art. $101 \S 4 \mathrm{k} . \mathrm{k}$. odrębnego terminu pomimo jego nietypowego określenia. Oznacza to, że termin ten będzie mógł być przerwany $^{23}$. Mimo to kwestia ta nie jest w pełni jasna, szkoda zatem, że nie została rozwiązana przez ustawodawcę, tym bardziej że istnieje w tej mierze możliwość, która ma szereg zalet obcych obecnemu rozwiązaniu.

Obecne rozwiązanie może wydłużyć termin przedawnienia karalności, ale nie musi tego czynić. Jest schematyczne - dotyczy jednakowo wszystkich wchodzących w grę typów czynów zabronionych, w odniesieniu do wszystkich wydłuża termin podobnie, co oznacza w praktyce, że w wypadku przestępstw drob-

17 Dz.U. z 2014 r., poz. 538.

18 M. Kulik, Przedawnienie..., s. 500-501.

19 A. Grześkowiak, [w:] Kodeks karny. Komentarz, red. A. Grześkowiak, K. Wiak, Warszawa 2015, s. 657.

20 M. Kulik, Przedawnienie..., s. 500; idem, Wydtużenie ..., s. 128 i n.

21 Pojawiają się wtedy dodatkowe komplikacje, o których szczegółowo pisze M. Kulik, Przedawnienie..., s. 499-500; idem, Wydtużenie..., s. 130.

22 M. Kulik, Przedawnienie..., s. 500; idem, Wydtużenie..., s. 130.

23 M. Kulik, Przedawnienie..., s. 500; idem, Wydtużenie..., s. 130. 
niejszych (o krótszym terminie przedawnienia karalności) termin ten naprawdę wydłuży, podczas gdy w odniesieniu do poważniejszych (o dłuższym terminie przedawnienia karalności) niczego nie zmieni. Nie bez znaczenia jest to, że konstrukcja, którą zastosowano, nie przystaje do rozwiązań znanych dotąd w polskim prawie karnym. Dlatego za słuszne uważam posłużenie się konstrukcją, która już istnieje. Należałoby wprowadzić w to miejsce konstrukcję spoczywania biegu terminu przedawnienia do ukończenia przez pokrzywdzonego 18. roku życia. Konstrukcja taka nie byłaby zresztą oryginalna. Zna ją prawo karne Malty (art. 208B k.k. Malty) ${ }^{24}$, Francji (art. 7 k.p.k. Francji) ${ }^{25}$, Słowenii (art. 90 ust. 3 k.k. Słowenii) ${ }^{26}$, Turcji (art. 66 ust. 6 k.k. Turcji) ${ }^{27}$, Islandii (art. 82 k.k. Islandii) ${ }^{28}$, Niemiec (§ 78 b k.k. Niemiec $)^{29}$.

Art. $101 \S 4$ k.k. mógłby stanowić, że termin przedawnienia karalności przestępstwa z art. 189a k.k. i przestępstw z rozdziału XXV k.k., a także przestępstw zagrożonych karą przekraczającą 3 lata (5 lat?) pozbawienia wolności popełnionych przez rodzica, opiekuna lub osobę sprawującą nad pokrzywdzonym pieczę, nie biegnie (spoczywa) ${ }^{30}$ do czasu ukończenia przez pokrzywdzonego 18 . roku życia ${ }^{31}$. Zmiana taka koniecznie musiałaby być połączona z modyfikacją art. 102. Przepis ten musiałby stanowić nie tak, jak obecnie, o wszczęciu postępowania w czasie biegu terminów określonych w art. 101 k.k., lecz o wszczęciu postępowania przed upływem tych terminów. W innym wypadku termin spoczywający nie zostałby przerwany w razie wszczęcia postępowania w czasie spoczywania terminu ${ }^{32}$.

Należy dodać, że w razie wprowadzenia zmiany, którą tu zaproponowano, może pojawić się pewna wątpliwość, która dotyczyłaby sytuacji, kiedy pokrzywdzony zmarł przed ukończeniem 18. roku życia. Być może należałoby uważać, że w takim wypadku termin przedawnienia karalności w ogóle nie biegnie, skoro zgodnie z proponowanym brzmieniem przepisu spoczywałby do ukończenia

${ }^{24}$ Przedawnienie jest w prawie Malty instytucją procesową.

25 Przedawnienie jest w prawie francuskim instytucją czysto procesową. Jego bieg w wypadku przestępstw seksualnych popełnionych z pokrzywdzeniem małoletniego rozpoczyna się z dniem osiągnięcia przez pokrzywdzonego pełnoletności.

${ }^{26}$ Wydaje się, że konstrukcję przedawnienia w prawie słoweńskim można uznać za procesową. Por. M. Kulik, Przedawnienie..., s. 710.

${ }^{27} \mathrm{~W}$ prawie karnym Turcji przedawnienie karalności jest skonstruowane jako instytucja czysto procesowa.

${ }^{28}$ Przedawnienie jest w islandzkim prawie karnym konstrukcją materialnoprawną. Spoczywanie biegu terminu na mocy art. 82 k.k. Islandii dotyczy niektórych wskazanych w ustawie przypadków i trwa do ukończenia przez pokrzywdzonego 14 lat. Por. M. Kulik, Przedawnienie ..., s. 726.

29 Przedawnienie jest $\mathrm{w}$ prawie niemieckim skonstruowane podobnie, jak w prawie polskim.

${ }_{30}$ Por. inne propozycje de lege ferenda M. Kulik, Przedawnienie..., s. 509-513.

${ }^{31}$ Propozycja ta jest nieco udoskonaloną wersją propozycji złożonej uprzednio (ibidem, s. 512-513).

${ }^{32}$ Szczegółowo: ibidem, s. 513. 
przez pokrzywdzonego 18. roku życia. Można też przyjąć wykładnię funkcjonalną - skoro celem przepisu jest umożliwienie pokrzywdzonemu dochodzenia sprawiedliwości, termin powinien zacząć biec z dniem jego śmierci. Być może warto byłoby to wyraźnie wyeksplikować w treści przepisu, który ostatecznie przyjąłby takie brzmienie: „Termin przedawnienia karalności przestępstwa $\mathrm{z}$ art. 189a k.k. i przestępstw z rozdziału XXV k.k., a także przestępstw zagrożonych karą przekraczającą 3 lata (5 lat?) pozbawienia wolności popełnionych przez rodzica, opiekuna lub osobę sprawującą nad pokrzywdzonym pieczę, nie biegnie (spoczywa) do czasu ukończenia przez pokrzywdzonego 18. roku życia lub do jego śmierci”.

Możliwość odmiennego rozwiązania zasygnalizowano nie po to, by wskazywać możliwe kierunki zmian przepisów dotyczących przedawnienia ${ }^{33}$, lecz po to, by wskazać, że wprowadzona zmiana nie wprowadza w gruncie rzeczy żadnej nowej jakości do uregulowania art. $101 \S 4$ k.k., poza dyskusyjnym wprowadzeniem tam występków przeciwko życiu i zdrowiu. Wydłużenie terminów o okres umożliwiający pokrzywdzonemu realne dochodzenie sprawiedliwości jest potrzebne ${ }^{34}$. Niewątpliwie funkcjonujący do niedawna termin 5-letni był zbyt krótki ${ }^{35}$. Jego automatyczne wydłużenie w 2014 r. do lat 10 usunęło tę najpoważniejszą wadę. W postaci nadanej ustawą z dnia 4 kwietnia 2014 r. o zmianie ustawy - Kodeks karny oraz niektórych innych ustaw ${ }^{36}$ miał on nadal wszystkie inne uprzednio wskazane wady. Wad tych nowelizacja z dnia 20 lutego 2015 r. nie usunęła, dodając nową, jaką jest zupełnie nieuzasadnione dołączenie występków przeciwko życiu i zdrowiu.

Uzupełnienie to postawiło szereg dodatkowych wątpliwości. Warto zauważyć, że o ile w odniesieniu do przestępstw seksualnych wskazano po prostu konkretny rozdział k.k., o tyle w wypadku przestępstw przeciwko życiu i zdrowiu opisano dobro prawne. Uprawnia to do postawienia pytania, czy chodzi o przestępstwa zawarte $w$ rozdziale dotyczącym przestępstw przeciwko życiu i zdrowiu, czy może także o te typy, w których życie i zdrowie jest ubocznym przedmiotem ochrony. Właśnie różnica w sposobie wskazania adekwatnych typów każe twierdzić, że w grę wchodzą również te typy, dla których życie i zdrowie stanowi tylko uboczny przedmiot ochrony ${ }^{37}$. To z kolei rodzi dalsze wątpliwości. Znajdują się

${ }^{33}$ Czynię to w innym miejscu: ibidem, s. 509-513.

${ }^{34}$ Wartość kryminalnopolityczną takiego rozwiązania uzasadnia bezdyskusyjnie T. Hörnle, Sollen Verjährungsfristen für des sexuellen Missbrauch von Minderjährigen verlängt werden?, „Goldtammer's Archiv für Strafrecht” 2010, z. 7, s. 389 i n.

${ }_{35}$ Młody człowiek zwykle przynajmniej przez jakiś czas od osiągnięcia pełnoletniości jest choćby częściowo uzależniony od rodziców lub innych osób, które wcześniej sprawowały nad nim pieczę i albo były sprawcami, albo nie dążyły do ścigania sprawców jego pokrzywdzenia. Por. M. Kulik, Przedawnienie..., s. 500.

${ }^{36}$ Dz.U. z 2014 r., poz. 538.

37 Tak trafnie S. Tarapata, [w:] Nowelizacja..., s. 792; idem, Kilka uwag na temat nowelizacji przepisów kodeksu karnego dotyczących instytucji przedawnienia oraz zatarcia skazania, „Palestra” 2015, nr 7-8, s. 136. 
tu nie tylko czyny umyślne, ale i nieumyślne, co samo w sobie nie byłoby jeszcze specjalnie interesujące. Warto zauważyć, że ujęte są też przestępstwa z narażenia dobra prawnego na niebezpieczeństwo abstrakcyjne. Trafnie zauważa S. Tarapata, że nie ma podstaw, by wyłączać stosowanie regulacji art. $101 \S 4$ k.k. do tych przepisów. Tytułem przykładu autor wskazuje na przepis art. 58 ust. 2 ustawy z dnia 29 lipca 2005 r. o przeciwdziałaniu narkomanii ${ }^{38}$ (udzielanie środka odurzającego małoletniemu, umożliwianie lub ułatwianie bądź nakłanianie go do użycia takiego środka) oraz znęcanie się ze szczególnym okrucieństwem ${ }^{39}$. Jest to dobry przykład typu, w przypadku którego życie i zdrowie jest przedmiotem ochrony pośrednim i dosyć dalekim. Warto jednak wskazać, że przy takim spojrzeniu można podać jeszcze mocniejsze przykłady. Właściwie w każdym przypadku znęcania się, niekoniecznie ze szczególnym okrucieństwem, można widzieć rodzaj zamachu na życie lub zdrowie ${ }^{40}$. O ochronie życia i zdrowia można mówić w wypadku chociażby art. 163 czy 164, właściwie wszystkich przestępstw przeciwko bezpieczeństwu w komunikacji, szeregu przestępstw przeciwko środowisku naturalnemu, jak choćby art. 184 k.k., niektórych przestępstw przeciwko działalności instytucji państwowych. Ewidentnym zamachem na zdrowie psychiczne człowieka jest zresztą cały szereg przestępstw seksualnych, ze zgwałceniem na czele. W grę wchodzi zatem w gruncie rzeczy znaczna, i to niedająca się z góry ograniczyć, liczba typów, z tym tylko chyba zastrzeżeniem, że muszą to być występki, a nie mogą to być zbrodnie. To ograniczenie, wyraźnie wynikające $\mathrm{z}$ treści znowelizowanego art. $101 \S 4$ k.k., nie jest konieczne, chociaż nie wydaje się mieć jakichś poważniejszych skutków. Przede wszystkim należy pamiętać, że terminy przedawnienia karalności zbrodni są dosyć długie - 30 lat dla typowej zbrodni przeciwko życiu i zdrowiu, 20 lat dla innych zbrodni. To sprawia, że w wypadku zabójstw mamy do czynienia z sytuacją, kiedy wydłużenie terminu do ukończenia 30. roku życia przez pokrzywdzonego nie będzie miało znaczenia praktycznego. Rzeczywiście jednak przy szerokim rozumieniu przestępstw przeciwko życiu i zdrowiu może dojść do sytuacji, które chyba nie były przez ustawodawcę zamierzone.

Przykładem takiej sytuacji może być rozbój na 5-letnim dziecku. Jeżeli uznamy, że rozbój z użyciem przemocy może stanowić w niektórych wypadkach zamach na zdrowie, to w takich wypadkach właśnie zdrowie będzie ubocznym przedmiotem ochrony. Do takich wypadków będzie miał zastosowanie art. 101 $\S 4$ k.k. Przedawnienie karalności nastąpi po upływie 25 lat, a jeżeli wszczęto w tym czasie postępowanie przeciwko osobie sprawcy - po 30. Jeżeli sprawca

38 T.j. Dz.U. z 2012 r., poz. 124.

39 S. Tarapata, [w:] Nowelizacja ..., s. 792-793.

${ }^{40}$ Por. pogłębione rozważania A. Wąska o przedmiocie ochrony znęcania się - A. Wąsek, J. Warylewski, [w:] Kodeks karny. Część szczególna. Komentarz, red. A. Wąsek, R. Zawłocki, t. 1, Warszawa 2010, s. 1193. Por. też: J. Kalinowski, Przestępstwo znęcania się (art. 184 k.k.) - przedmiot ochrony, „Ruch Prawniczy, Ekonomiczny i Socjologiczny” 1985, z. 1, s. 155-156. 
posłuży się bronią palną, nożem lub innym podobnie niebezpiecznym przedmiotem lub środkiem obezwładniającym albo będzie działał w inny sposób bezpośrednio zagrażający życiu lub wspólnie z inną osobą, która posługuje się taką bronią, przedmiotem lub środkiem, popełni zbrodnię z art. $280 \S 1$ k.k., termin przedawnienia karalności tej zbrodni upłynie po 20 latach, a w razie wszczęcia w tym terminie postępowania przeciwko osobie sprawcy - po 25 latach. Rozwiązanie, o którym mowa, nie jest zatem udane, aczkolwiek można przyznać, że jego praktyczne znaczenie nie będzie duże ${ }^{41}$. Mimo to słuszne byłoby chyba - skoro już ustawodawca zdecydował się na wprowadzenie przestępstw przeciwko życiu do art. $101 \S 4$ k.k. ${ }^{42}$ - gdyby mowa w nim była nie o występkach, lecz o przestępstwach.

Niewątpliwe zasadniczym celem istnienia omawianej regulacji było wzmożenie ochrony małoletnich przed wykorzystaniem seksualnym ${ }^{43}$. I w tym zakresie przepis został zmodyfikowany. Zmiana, o której mowa, jest w pewnym sensie trudna do oceny, ponieważ można mieć wątpliwość, czy ma ona znaczenie merytoryczne, czy tylko stylistyczne.

Należy przypomnieć, że przed wejściem w życie ustawy z dnia 20 lutego 2015 r. w przepisie była mowa o przestępstwach określonych w rozdziale XXV (Przestępstwa przeciwko wolności seksualnej i obyczajności) w przypadku, kiedy pokrzywdzony jest małoletni. Obecnie w zakresie, o którym teraz mowa, przepis będzie dotyczył przestępstw określonych w rozdziale XXV, popełnionych na szkodę małoletniego albo gdy treści pornograficzne obejmują udział małoletniego.

Czy wskazana zmiana ma w ogóle charakter merytoryczny? Uprzednio chodziło o sytuację, kiedy pokrzywdzony był małoletni. Obecnie natomiast o wypadek, kiedy pokrzywdzony jest małoletni, a także o przypadek, kiedy treści pornograficzne obejmują udział małoletniego. Wypadałoby założyć, że w tym ostatnim przypadku małoletni biorący udział w treści pornograficznej nie są pokrzywdzeni. Byłoby wysoce dziwne, gdyby tak było. Słusznie zauważa się w literaturze przedmiotu, że małoletni jest $\mathrm{w}$ wypadku przestępstw polegających na produkowaniu itp. treści pornograficznych - pokrzywdzonym ${ }^{44}$. Ma całkowitą rację A. Grześkowiak, stwierdzając, że sfor-

${ }^{41} \mathrm{O}$ wyrazistszy, lecz niestety chybiony przykład pokusił się S. Tarapata. Zwraca on uwagę, że w wypadku spowodowania ciężkiego uszczerbku na zdrowiu u rocznego dziecka przedawnienie karalności nastąpi zgodnie z art. 101 § 4 k.k. po 29 latach, a w razie przerwania biegu terminu - po 34, gdy karalność takiego samego czynu popełnionego w ramach ludobójstwa nastąpi po 20 latach. Zob. S. Tarapata, [w:] Nowelizacja ..., s. 793-794. Autor myli się, gdyż z uwagi na treść art. 105 k.k. karalność ludobójstwa w ogóle nie podlega przedawnieniu.

${ }^{42}$ Co - jak wskazano wyżej - nie jest samo w sobie uzasadnione.

43 A. Grześkowiak, op. cit., s. 657; M. Leciak, [w:] Kodeks karny. Komentarz, red. R.A. Stefański, Warszawa 2015, s. 600-601.

${ }^{44}$ S. Tarapata, [w:] Nowelizacja..., s. 797; A. Grześkowiak, op. cit., s. 657. Chodzi, rzecz oczywista, o przypadki, kiedy da się wyodrębnić pokrzywdzonego, co wszakże nie różni stanu prawnego po nowelizacji od poprzedniego. 
mułowanie „przestępstwo określone w rozdziale XXV k.k. popełnione na szkodę małoletniego, albo gdy treści pornograficzne obejmują udział małoletniego" odpowiada po prostu określeniu ,przestępstwo seksualne na szkodę małoletniego" ${ }^{45}$.

W takim wypadku powstaje wątpliwość, czemu właściwie miałaby służyć nowelizacja. Być może rację ma S. Tarapata, twierdząc, że chodzi o przypadki, kiedy sprawca dopuszcza się czynu w sytuacji, kiedy pokrzywdzony biorący udział w treści pornograficznej jest już dorosły, a ktoś tę treść ogląda (art. $202 \S 4 \mathrm{c}$ k.k.). W takim wypadku okoliczność, że pokrzywdzony jest obecnie dorosły, nie miałaby znaczenia - termin przedawnienia byłby już wydłużony ${ }^{46}$. Być może tak właśnie jest, lecz w przypadku, o którym pisze S. Tarapata, rola nowelizacji byłaby tylko klaryfikująca. Sądzę bowiem, że i w poprzednim brzmieniu przepisu dałoby się uzasadnić wydłużenie karalności. Samo stwierdzenie, że chodzi o przypadek, kiedy pokrzywdzony jest małoletni ${ }^{47}$, nie oznacza przecież, że ma być małoletni w czasie popełniania czynu polegającego np. na posiadaniu treści pornograficznych. Wystarczy, jeżeli w treści zapisu pornograficznego znajduje się małoletni, który był takim w czasie sporządzania zapisu. Sądzę, że zmiana ta niczego nie wniosła. Być może w grę wchodzi tu wyjaśnienie wątpliwości, w mojej opinii jednak takowych nie było. Wartość wprowadzonej zmiany jest więc dyskusyjna.

$\mathrm{Za}$ istotną należy uznać zmianę $\mathrm{w}$ treści art. 102 k.k. Przepis ten przywraca jednolity, 5-letni okres, o który ulega wydłużeniu termin przedawnienia karalności w razie jego przerwania, a likwiduje istniejące dotychczas dwa okresy: 5-letni i 10-letni. Ponieważ zmiana ta dotyczy przedawnienia karalności, a więc instytucji materialnej, często będzie się pojawiać potrzeba stosowania art. $4 \S 1$ k.k. ${ }^{48}$ Natomiast samo pojawienie się tej zmiany narzuca pytanie, jakie względy nakazały jednocześnie ustawodawcy utrzymać art. $44 \S 5$ k.k.s. w dotychczasowym brzmieniu. Obecnie mamy bowiem do czynienia z sytuacją, w której w razie przerwania terminu przedawnienia karalności określonego w kodeksie karnym zostaje on wydłużony o 5 lat, gdy w razie przerwania terminu przedawnienia karalności przestępstwa skarbowego wydłużenie karalności o 5 lat dotyczy tylko przestępstw zagrożonych

${ }^{45}$ A. Grześkowiak, op. cit., s. 657.

46 S. Tarapata, [w:] Nowelizacja..., s. 798.

47 Art. $101 \S 4$ k.k. sprzed nowelizacji.

${ }^{48} \mathrm{Na}$ marginesie warto zauważyć, że przedawnienie karalności jest instytucją prawa karnego materialnego, lecz bieg jego terminu jest przerywany przez zdarzenie procesowe, jakim jest wszczęcie postępowania przeciwko osobie sprawcy. Jest to dobry przykład materialnych skutków zastosowania przepisów procesowych i kolejny dowód na to, że okoliczność, że pewna instytucja (w tym przypadku wszczęcie postępowania przeciwko osobie) wywołuje skutek materialnoprawny (w tym przypadku wydłużenie terminu przedawnienia karalności), nie stanowi dowodu, że jest to instytucja materialna. Nie inaczej jest moim zdaniem w analizowanym wyżej przykładzie przedawnienia wykonania kary. Uważam je za instytucję procesową. To, że wywołuje skutki na gruncie prawa karnego materialnego (jak uruchomienie biegu terminu zatarcia skazania), nie dowodzi jego materialnego charakteru. 
karą grzywny, ograniczenia wolności lub pozbawienia wolności do lat 3. W wypadku przestępstw zagrożonych karą pozbawienia wolności przekraczającą 3 lata termin przerwany zostaje wydłużony o 10 lat. Pytanie to, rzecz jasna, jest retoryczne, należy bowiem wnosić, że ustawodawca niczym się nie kierował, gdyż autorzy projektu po prostu nie wiedzieli o unormowaniu przedawnienia w k.k.s.

Ustawa nowelizująca k.k. usunęła art. $104 \S 2$ k.k., który stanowił, że przedawnienie $\mathrm{w}$ stosunku do przestępstw określonych $\mathrm{w}$ art. 144, art. $145 \S 2$ lub 3, art. $338 \S 1$ lub 2 oraz art. 339 biegnie od chwili uczynienia zadość obowiązkowi albo od chwili, w której na sprawcy obowiązek przestał ciążyć. Uchylenie tego przepisu niewiele zmieni w kształcie instytucji. Na gruncie dotychczasowego stanu prawnego można było mieć wrażenie, że regulacja ta miała charakter wyjątkowy $^{49}$, choć w znacznej mierze było to ustawowe superfluum ${ }^{50}$. Wprowadzenie zmiany, do której doszło, powoduje, że znikają wątpliwości, iż do wskazanych typów stosuje się po prostu reguły określone w art. $104 \S 2$ k.k. Zmianę tę można zatem ocenić pozytywnie. Wolno sądzić, że teoria i praktyka poradzą sobie z ustalaniem początku biegu terminu przedawnienia karalności nawet (a może zwłaszcza) w braku szczegółowego unormowania w tej mierze.

Nie bez znaczenia dla wykładania przepisów o przedawnieniu jest okoliczność pojawienia się w kodeksie karnym nowej kategorii środków penalnych $\mathrm{w}$ postaci środków kompensacyjnych. W dotychczasowym stanie prawnym możliwe było orzekanie obowiązku naprawienia szkody, zadośćuczynienia lub nawiązki w przypadku, gdyby doszło do przedawnienia na gruncie prawa cywilnego ${ }^{51}$. Art. $46 \S 1$ k.k. w brzmieniu ustalonym nowelizacją przesądza jednak, że w przypadku orzeczenia obowiązku naprawienia szkody i zadośćuczynienia za doznaną krzywdę stosuje się przepisy prawa cywilnego. Obejmuje to także przepisy o przedawnieniu roszczeń. Nie można więc orzekać tych środków nie tylko w razie przedawnienia karalności, ale i w razie przedawnienia roszczenia $\mathrm{w}$ prawie cywilnym ${ }^{52}$. Należy podkreślić, że w przypadku, gdy karalność przestępstwa ulegnie przedawnieniu, ale nie

${ }^{49}$ Por. B. Kunicka-Michalska, [w:] Kodeks karny. Czesść ogólna. Komentarz, red. G. Rejman, Warszawa 1999, s. 379; M. Kulik, Przedawnienie..., s. 366.

${ }^{50}$ Uzasadnienie rządowego projektu..., s. 27; M. Hermanowicz, op. cit., s. 63; K. Banasik, op. cit., s. 147; M. Kulik, Przedawnienie..., s. 367. Autor niniejszych słów w uprzednim stanie prawnym prezentował mniejszościowy pogląd, że uchylony przepis tylko w pewnym zakresie stanowi superfluum (ibidem, s. 366-368). Nie bez znaczenia była okoliczność, że przy wykładaniu przepisów prawnych trudno uznawać niektóre z nich za zbędne i pozbawione treści.

${ }^{51}$ Ibidem, s. 590; S. Tarapata, [w:] Nowelizacja ..., s. 781.

52 Tak S. Tarapata, [w:] Nowelizacja..., s. 781. Por. Uzasadnienie rzadowego projektu kodeksu karnego, [w:] Nowe kodeksy karne z uzasadnieniami, Warszawa 1997, s. 28; M. Hermanowicz, op. cit., s. 66; A. Sakowicz, Opinia prawna na temat projektu ustawy o zmianie ustawy - Kodeks karny oraz niektórych innych ustaw (druk sejmowy nr 2393) z dnia 23 VI 2014 r., http://orka.sejm.gov.p1/RexDomk7. nsf/0/61FF704BF2911580C1257D0200257BC6/\$file/i1496_14.rtf [data dostępu: 02.11.2015]. 
przedawni się roszczenie cywilne, orzeczenie środka kompensacyjnego w postępowaniu karnym będzie niemożliwe ${ }^{53}$.

Wydaje się, że stosowanie przepisów prawa cywilnego obejmuje także nawiązkę zastępczą orzekaną na podstawie art. $46 \S 2$ k.k. ${ }^{54}$

Wprowadzenie $\mathrm{w}$ omawianym zakresie regulacji cywilnoprawnych rodzi cały szereg konsekwencji wynikających z istoty przedawnienia na gruncie prawa cywilnego (np. konieczność podniesienia zarzutu przedawnienia roszczenia, możliwość zrzeczenia się zarzutu przedawnienia) $)^{55}$. Słusznie - jak się wydaje - pisze S. Tarapata, że skuteczne podniesienie przez sprawcę zarzutu przedawnienia roszczenia będzie miało skutek nie tylko w obrębie samego obowiązku naprawienia szkody na podstawie art. $46 \S 1$ k.k., lecz i na innej podstawie, np. przy stosowaniu środka probacyjnego ${ }^{56}$.

Nie doszło do bezpośrednich zmian w zakresie przedawnienia wykonania kary. Wprowadzono tu tylko pewne modyfikacje wynikające ze zmian innych przepisów. Art. 15 § 4 k.k.w. otrzymał bowiem następujące brzmienie: „Wykonywanie kary pozbawienia wolności, zastępczej kary pozbawienia wolności, kary aresztu wojskowego, kary aresztu lub zastępczej kary aresztu, kary porządkowej oraz środka przymusu skutkującego pozbawieniem wolności w tej samej lub innej sprawie, wstrzymuje bieg przedawnienia”. Zmiana, do jakiej doszło, polega w tym wypadku na tym, że w obecnym stanie prawnym spoczywanie biegu terminu przedawnienia wykonania kary dotyczy nie tylko wykonywania kar, lecz i środków karnych, środków zabezpieczających, kosztów procesu.

W zakresie wykonania środków karnych nastąpiła zmiana art. $103 \S 2$ k.k., który w obecnym brzmieniu stanowi już nie o odpowiednim stosowaniu art. $103 \S 1$ pkt 3 k.k. do środków karnych wymienionych w art. 39 pkt. 1-4 oraz 6 i 7, a art. $103 \S 1$ pkt 2 k.k. do środka karnego wymienionego w art. 39 pkt 5 k.k., lecz że art. $103 \S 1$ pkt 3 ma zastosowanie odpowiednio do środków karnych, środków kompensacyjnych i przepadku. Pojawi się zatem jednolity, 10-letni termin przedawnienia karalności, co usunie szereg wątpliwości istnie-

${ }^{53}$ S. Tarapata, [w:] Nowelizacja ..., s. 781-782.

${ }^{54}$ Nie dotyczy to jednak nawiązki orzekanej na podstawie art. 47. Słusznie wskazuje się w doktrynie, że środek ten nie ma charakteru czysto kompensacyjnego. Zob. M. Iwański, [w:] Nowelizacja ..., s. 203; S. Tarapata, [w:] Nowelizacja ..., s. 788. Wolno natomiast mieć wątpliwości w odniesieniu do nawiązki orzekanej na podstawie art. 290 § 2 k.k. Jej kompensacyjny charakter jest oczywisty, lecz jej wysokość określona jako podwójna wartość drzewa, a także orzekanie jej w pełnej wysokości od każdego ze współdziałających nadają jej też wymiar represyjny. Sądzę zatem, że w jej wypadku, podobnie jak w wypadku nawiązki orzekanej na podstawie art. 47 k.k., zarzut przedawnienia roszczenia nie jest dopuszczalny.

55 S. Tarapata, [w:] Nowelizacja..., s. 784-786.

56 Ibidem, s. 786. 
jących $\mathrm{w}$ dotychczasowym stanie prawnym ${ }^{57}$, a zatem musi to być ocenione pozytywnie.

Ustawodawca nie zdecydował się natomiast na pozytywną regulację w zakresie środków zabezpieczających, co zapewne będzie oznaczać, że podział w doktrynie co do możliwości przedawnienia ich wykonania utrwali się, aczkolwiek wydaje się, że mając świadomość wątpliwości w tym zakresie, ustawodawca - gdyby chciał ją przesądzić na korzyść stanowiska, zgodnie z którym wykonanie środków karnych podlega przedawnieniu - uczyniłby to. Autor niniejszych słów zdaje sobie sprawę, że argumentum ex silentio mogłoby być w danym wypadku uważane za słabe. $Z$ drugiej strony długotrwała dyskusja nad zagadnieniem ${ }^{58}$ uprawnia do przekonania, że projektodawca miał wiedzę na temat braku stosownej regulacji odnośnie do przedawnienia wykonania środków zabezpieczających. Jej brak nie świadczy o istnieniu luki, którą należałoby uzupełniać w drodze analogii, lecz o tym, iż nie przewidywano potrzeby wprowadzania przedawnienia wykonania środków zabezpieczających ${ }^{59} . \mathrm{Z}$ innych powodów również należy podtrzymać wypowiedziane już stanowisko, że wykonanie środków zabezpieczających nie podlega przedawnieniu ${ }^{60}$. Środki zabezpieczające nie są bowiem środkiem reakcji prawnokarnej, lecz narzędziem reakcji na niebezpieczeństwo, które tworzy spraw$\mathrm{ca}^{61}$. Znaczny upływ czasu od orzeczenia środka może być ewentualnie dowodem na to, że zagrożenie, które stanowi sprawca, zmniejsza się, a nawet całkowicie odpada $^{62}$. Podobnie wolno uważać, że znaczny upływ czasu od popełnienia czynu zabronionego zmniejsza ryzyko, że sprawca popełni czyn ponownie, a niekiedy je nawet wyłączy ${ }^{63}$, jednak założenie, że w grę wchodzi przedawnienie karalności i przedawnienie wykonania środka jawi się jako wysoce wątpliwe. Można go bronić tylko przy dwojakim założeniu, mianowicie: 1) środki zabezpieczające są surogatem kary $\left.{ }^{64}, 2\right)$ pojęcia „czyn zabroniony” i „przestępstwo” mogą być uży-

57 Por. szczegółowo: M. Kulik, Przedawnienie..., s. 590 i n.; L. Wilk, [w:] Kodeks karny. Komentarz, red. M. Filar, Warszawa 2013, s. 531; A. Sakowicz, [w:] Kodeks karny. Czesść ogólna. Komentarz, red. M. Królikowski, R. Zawłocki, t. 2, Warszawa 2010, s. 829-830.

${ }^{58}$ Szczegółowo relacjonowana przez K. Banasik (op. cit., s. 55).

${ }_{59}$ M. Pyrcak, [w:] Nowelizacja ..., s. 763.

${ }^{60}$ M. Kulik, Przedawnienie..., s. 601.

${ }^{61}$ Por. A. Barczak-Oplustil, [w:] Nowelizacja ..., s. 685-687.

${ }_{62}$ M. Pyrcak, op. cit., s. 763; M. Kulik, Przedawnienie..., s. 601.

${ }^{63}$ M. Kulik, Przedawnienie..., s. 601. Należy pamiętać, że (przy przyjęciu takiego poglądu) orzekanie o środku zabezpieczającym będzie jednak niedopuszczalne w sytuacji, kiedy czyn zabroniony stanowił przestępstwo (nie została wyłączona wina, np. czyn popełniono w związku z uzależnieniem od alkoholu, które jednak nie skutkowało niepoczytalnością).

${ }^{64}$ Tak wprost S. Tarapata, [w:] Nowelizacja ..., s. 814-815. Wydaje się, że zastrzeżenie, iż chodzi o utożsamienie tych środków tylko na gruncie jednego (XI) rozdziału k.k. jest trudne do obrony. Jeżeli pojęcia te dają się utożsamić, należy stosować to konsekwentnie. Jeżeli nie dają się utożsamić, nie należy tego czynić. 
wane zamiennie ${ }^{65}$. Oba założenia można jednak kwestionować. Wyżej wyrażono pogląd, że środek zabezpieczający różni od kary i charakter, i cel. Utożsamić się ich nie da ${ }^{66}$. Tym bardziej nie da się utożsamić przestępstwa $\mathrm{z}$ czynem zabronionym. Wypada zatem stwierdzić, że nadal brak danych, by uważać, że orzekanie i wykonywanie orzeczonych środków zabezpieczających podlega przedawnieniu $^{67}$, a ostatnia nowelizacja niczego $\mathrm{w}$ tym zakresie nie zmieniła.

\section{BIBLIOGRAFIA}

Banasik K., Przedawnienie w prawie karnym w systemie kontynentalnym i anglosaskim, Warszawa 2013.

Barczak-Oplustil A., [w:] Nowelizacja prawa karnego 2015. Komentarz, red. W. Wróbel, Kraków 2015.

Grześkowiak A., [w:] Kodeks karny. Komentarz, red. A. Grześkowiak, K. Wiak, Warszawa 2015.

Hermanowicz M., Przedawnienie w świetle projektów zmian kodeksu karnego, „Ius Novum” 2015, nr 1.

Hörnle T., Sollen Verjährungsfristen für des sexuellen Missbrauch von Minderjährigen verlängt werden?, „Goldtammer's Archiv für Strafrecht” 2010, z. 7.

Iwański M., [w:] Nowelizacja prawa karnego 2015. Komentarz, red. W. Wróbel, Kraków 2015.

Kalinowski J., Przestępstwo znęcania się (art. 184 k.k.) - przedmiot ochrony, „Ruch Prawniczy, Ekonomiczny i Socjologiczny" 1985, z. 1.

Kulik M., Przedawnienie karalności i przedawnienie wykonania kary w polskim prawie karnym, Warszawa 2014.

Kulik M., Wydtużenie terminów przedawnienia karalności przestępstw przeciwko wolności seksualnej i obyczajności popetnionych z pokrzywdzeniem małoletnich, „Zeszyty Naukowe Wyższej Szkoły Humanistyczno-Ekonomicznej w Zamościu" 2012, nr 6.

Kunicka-Michalska B., [w:] Kodeks karny. Część ogólna. Komentarz, red. G. Rejman, Warszawa 1999.

Leciak M., [w:] Kodeks karny. Komentarz, red. R.A. Stefański, Warszawa 2015.

Majewski J., Kodeks karny. Komentarz do zmian 2015, Warszawa 2015.

Marek A., Kodeks karny. Komentarz, Warszawa 2010.

Marszał K., Przedawnienie w prawie karnym, Warszawa 1972.

Mozgawa M., Budyn-Kulik M., Prawnokarne aspekty pedofilii. Analiza dogmatyczna i wyniki badań empirycznych, „Czasopismo Prawa Karnego i Nauk Penalnych” 2006, z. 2.

Pyrcak M., [w:] Nowelizacja prawa karnego 2015. Komentarz, red. W. Wróbel, Kraków 2015.

Sakowicz A., [w:] Kodeks karny. Część ogólna. Komentarz, red. M. Królikowski, R. Zawłocki, t. 2, Warszawa 2010.

Sakowicz A., Opinia prawna na temat projektu ustawy o zmianie ustawy - Kodeks karny oraz niektórych innych ustaw (druk sejmowy nr 2393) z dnia 23 VI 2014 r., http://orka.sejm.gov.pl/

${ }^{65}$ Przypomnieć należy, że przedawnieniu podlega karalność przestępstw i wykonanie kar, gdy w wypadku środków zabezpieczających podstawą orzekania nie jest popełnienie przez sprawcę przestępstwa, lecz orzeczenie czynu zabronionego.

${ }^{66}$ Por. przypis 63.

${ }^{67}$ Tak też (zresztą w różnym zakresie, gdyż niektórzy autorzy wypowiadali się tylko na temat przedawnienia orzekania środków zabezpieczających lub przedawnienia ich wykonania) np. S. Śliwiński, Polskie prawo karne materialne, Warszawa 1946, s. 545; K. Marszał, Przedawnienie w prawie karnym, Warszawa 1972; M. Leciak, op. cit., s. 598; M. Pyrcak, op. cit., s. 763; A. Marek, Kodeks karny. Komentarz, Warszawa 2010, s. 288; Z. Sienkiewicz, [w:] M. Bojarski, J. Giezek, Z. Sienkiewicz, Prawo karne materialne. Część ogólna i szczególna, Warszawa 2004, s. 362-363; L. Wilk, op. cit., s. 657. 
RexDomk7.nsf/0/61FF704BF2911580C1257D0200257BC6/\$file/i1496_14.rtf [data dostępu: 02.11.2015].

Sienkiewicz Z., [w:] M. Bojarski, J. Giezek, Z. Sienkiewicz, Prawo karne materialne. Czesść ogólna i szczególna, Warszawa 2004.

Sitarz O., Problem przedawnienia w prawie polskim i orzecznictwie ETPCz na tle przestepstw popetnionych na szkodę małoletnich, [w:] Czas i jego znaczenie w prawie karnym, red. J. Warylewski, Gdańsk 2010.

Śliwiński S., Polskie prawo karne materialne, Warszawa 1946.

Tarapata S., [w:] Nowelizacja prawa karnego 2015. Komentarz, red. W. Wróbel, Kraków 2015.

Tarapata S., Kilka uwag na temat nowelizacji przepisów kodeksu karnego dotyczacych instytucji przedawnienia oraz zatarcia skazania, „Palestra” 2015, nr 7-8.

Uzasadnienie rzadowego projektu kodeksu karnego, [w:] Nowe kodeksy karne z uzasadnieniami, Warszawa 1997.

Uzasadnienie rządowego projektu ustawy z dnia 15 kwietnia $2014 \mathrm{r}$.

Waltoś S., Proces karny. Zarys systemu, Warszawa 2009.

Wąsek A., Warylewski J., [w:] Kodeks karny. Część szczególna. Komentarz, red. A. Wąsek, R. Zawłocki, t. 1, Warszawa 2010.

Wilk L., [w:] Kodeks karny. Komentarz, red. M. Filar, Warszawa 2013.

\section{SUMMARY}

The article concerns the basic legal consequences of the amendment of the Criminal Code on $20^{\text {th }}$ of February 2015 in terms of limitation criminality and enforcement of the sentence. There are presented the changes introduced an amendment to their legal effects, signaling errors and any perceived need for further changes to the regulations.

Keywords: limitation; amendment; Criminal Code

\section{STRESZCZENIE}

Artykuł dotyczy podstawowych skutków prawnych nowelizacji Kodeksu karnego z dnia 20 lutego 2015 r. w zakresie przedawnienia karalności i przedawnienia wykonania kary. Przedstawiono zmiany wprowadzane nowelizacją, ich skutki prawne, sygnalizując dostrzeżone błędy i ewentualne potrzeby w zakresie dalszych zmian przepisów.

Słowa kluczowe: przedawnienie; nowelizacja; Kodeks karny 